\title{
COPING WITH STRESSORS IN LATE ADOLESCENCE/YOUNG ADULTHOOD: A SALUTOGENIC PERSPECTIVE
}

\author{
Ann-Marie K Hutchinson \\ MA (Psychology) \\ Student, Department of Psychology, University of Johannesburg, Johannesburg \\ Corresponding author: hutchinsons@absamail.co.za
}

\author{
Anita D Stuart \\ D Litt et Phil \\ Professor, Department of Psychology, University of Johannesburg, Johannesburg
}

\author{
Hester G Pretorius \\ D Litt et Phil (Psychology) \\ Professor \\ Director, Institute for Child and Adult Guidance, University of Johannesburg, Johannesburg
}

Keywords: stress; coping; meaning; salutogenesis; adolescence/young adulthood; health; well-being; sense of coherence

\begin{abstract}
Literature indicates that globally young people are increasingly experiencing life as hopeless and meaningless. It is thus beneficial to investigate factors facilitating well-being in young people, as they are required to cope with multiple stressors whilst simultaneously negotiating the transition from childhood to adulthood. Health practitioners need to establish ways to enhance adequate coping in young people in order to minimise stress and ward off negative consequences such as addiction, depression and other pathologies that compromise health. This study aimed to ascertain whether discovering meaning in life and developing a strong sense of coherence may predict coping with stressors in a group of male and female South Africans in late adolescence/young adulthood ( $N=258)$. Three self-report measures were used: the Purpose in Life Questionnaire to measure the extent to which one has found meaning, the Sense of Coherence Scale to assess the extent to which individuals view life as comprehensible, manageable and meaningful, and the Adolescent Coping Scale to determine ability to cope. Logistic regression analysis results indicate that the extent to which one has discovered meaning in life and developed a sense of coherence predict ability to cope in young people. This suggests that intervention strategies that encourage individuals to search for meaning and strengthen sense of coherence may be effective in facilitating coping and may contribute positively to the overall health of young people.
\end{abstract}

\begin{abstract}
ABSTRAK
Literatuur dui aan dat alhoemeer jong volwassenes hulle lewens as leeg en betekenloos ervaar. Dit is dus voordelig om die verhouding tussen welsyn en die hantering van stres by jong volwassenes te ondersoek, aangesien hulle deur talle stresfaktore gekonfronteer word, en gelyktydig die oorgang tussen kinderjare en volwassenheid suksesvol moet hanteer. Gesondheidspraktisyns moet riglyne daarstel om stres te minimaliseer, en om negatiewe en ongewenste gevolge soos verslawing, selfmoord, depressie en ander patologieë wat gesondheid negatief beïnvloed te bekamp. Dié studie is daarop gerig om te bepaal of die mate waarin ' $n$ individu se sin van betekenis in die lewe en die mate van samehangendheidsin, aanduidend is van hoe jong manlike/vroulike Suid-Afrikaanse volwassenes stresfaktore hanteer $(N=258)$. Drie self-verslaggewende metings is gebruik. Die "Purpose in Life"-vraelys is gebruik om te bepaal in watter mate ' $n$ individu sy/haar betekenis of doel in die lewe ontdek het. Ten einde te bepaal tot watter mate ' $n$ individu die lewe as verstaanbaar, beheerbaar en betekenisvol beskou, is die "Sense of Coherence"-skaal
\end{abstract}


gebruik. Die "Adolescent Coping Scale" is gebruik om die opgewassendheid van die deelnemers te bepaal. Logistiese regressie-uitslae dui daarop aan dat die mate waarop individue hulle samehangendheidsin ontwikkel en hul sin van betekenis in die lewe ontdek, gekoppel is aan hulle vermoë om effektiewe hanteringstrategieë te kies. Die bogenoemde dui aan dat strategieë wat individue aanmoedig om betekenis in die lewe na te streef, en hul saamhangendheidsin te versterk, effektief mag wees in die fasilitering van hanteringstrategieë en dat dit, positief mag bydra tot die algehele gesondheid van jong volwassenes.

\section{INTRODUCTION AND LITERATURE RE- VIEW}

While historically much research has been conducted on the health of individuals in terms of stress and coping (for example, Lazarus \& Folkman, 1984:1-464; Strümpfer, 1995:81-87), a more current debate among theorists highlighted the possibility that not enough progress has been made in stress and coping research (Coyne \& Racioppo, 2000:655-664; Lazarus, 2000:665673; Seligman \& Csikszentmihalyi, 2000:5-14; Seligman, Steen, Park \& Peterson, 2005:410-421; Somerfield \& McCrae, 2000:620-625). It seems that more research in the field is necessary in order to mediate stress, and that this is especially true for young people, because individuals in late adolescence/young adulthood need to successfully negotiate the transition between childhood and adulthood while being constantly faced with stressors as well as being required to make major life decisions.

Frydenberg and Lewis (1993:1-233; 2004:25-37) indicate that health-compromising demands and stressors are increasingly placed on young individuals, as job competition and other pressures rise in comparison to previous years. These stressors may include one or more of the following: seeking employment, pursuing tertiary education, relationships with others, exposure to national and international occurrences, and work and daily life stressors involving adaptation to technology and other demands. Certain developmental life stages and stressful events give emphasis to the question of meaning in life for most individuals (Leider, 1997:1-162). This is especially true in the late adolescence/early adulthood life phase, as more and more young people are reportedly experiencing life as hopeless and meaningless (Reivich, Gillham, Chaplin \& Seligman, 2005:223-237; Santrock, 2003:1-495). This life phase is characterised by the freedom individuals have to make life choices, and the increasing levels of awareness regarding the effect of current decisions on the rest of their adult lives. Thus existential concerns are particularly significant during late adolescence/young adulthood, and young people often experience their lives as less meaningful than older adults (Damon, Menon \& Bronk, 2003:119-128; Reker, Peacock \& Wong, 1987:44-49; Van Ranst \& Marcoen, 1997:877-884).

The suggestion that meaning in life motivates individuals and contributes to their overall health is a pivotal idea in psychology, a proposition offered by Viktor Frankl (1905-1997). He argues that, regardless of one's circumstances, life has meaning and that every individual has the capacity and responsibility to find meaning in life, even during times of stress and crisis (Frankl, 1992:1-165). The construct of meaning in life has influenced psychological models of stress and coping by emphasising how an individual who perceives life as meaningful may alleviate stress and maintain coping (Lazarus, 2000:665-673; Zika \& Chamberlain, 1992:133145). Meaning is one aspect of the sense of coherence, which is a central construct in the salutogenic approach to health (Antonovsky, 1987:1-218).

Salutogenesis, a theory developed by Aaron Antonovsky (1923-1994), emphasises the importance of what is known as sense of coherence. Sense of coherence is characterised by an individual's level of comprehensibility, manageability and meaningfulness, and the construct refers to why some people function better under stressful situations than others and are able to create meaning arising from complicated circumstances and maintain health. The pathogenic paradigm focuses on the development and maintenance of illness and disease, the salutogenic paradigm emphasises the origins and factors contributing to the development of health, and theorists and therapists are beginning to investigate health in terms of discovering wellness and what maintains wellness (for example, Antonovsky, 1979:1-255, 1987:1-218; Strümpfer, 1995:81-87; Zika \& Chamberlain, 1992:133-145). Antonovsky's (1987:1218) position regarding health is that disease and stres- 
sors are inevitable and he thus encourages individuals to actively pursue adaptive coping strategies. The salutogenic paradigm focuses on the functioning of the individual under stressful circumstances, and it seems possible from a salutogenic perspective that developing a strong sense of coherence may facilitate coping (Antonovsky, 1987:1-218).

Psychological well-being incorporates both meaning in life and sense of coherence, and these constructs may have an impact on an individual's functioning in terms of ability to cope with stressors. Although different individuals cope with stressors in many different ways, the way adolescents/young adults cope with stressors may establish patterns for adulthood (Frydenberg \& Lewis, 1993:1-233). Individuals in the late adolescent/young adulthood life stage are in a turbulent, dynamic and restless phase marked by many transitions (Santrock, 2003:1-495). The challenges and changes faced by young people, and the role requirements of these individuals can lead to stress and this can have major health consequences in developmental, emotional, social, academic and general life spheres as they enter adulthood. It is evident that research is needed regarding well-being in late adolescence/young adulthood in order to assess how young people cope with stressors.

Previous research has investigated well-being, including meaning in life and salutogenic measures, on adults who are well-established in their lives and careers, and some relatively specific samples, such as aged populations, terminally ill individuals and workplace employees (for example, Marais \& Stuart, 2005:89-105; Shek, 2003:185-200; Strümpfer \& Mlonzi, 2001:30-38; YiuKee \& Tang, 1995:220-230). However, research is needed on young people in South Africa in order to ascertain how they cope with stressors, including stressors that may be country-specific. For example, in postapartheid South Africa young people are frequently faced with unemployment, high levels of crime and persisting racial and political tension (Brown, 2001: 269-298). Health practitioners need to establish ways to enhance adequate coping in young people in order to minimise their stress and divest them of the negative and healthcompromising consequences of stressors, for example, addictions, suicide, depression and other pathologies (Frydenberg \& Lewis, 2004:25-37).

The relationship between how individuals perceive mean- ing in life or to what extent these individuals believe they have found meaning, their development of a sense of coherence, and their experience of coping with stress needs to be investigated. Furthermore, meaning in life and sense of coherence as components of psychological well-being ought to be explored in order to ascertain how people may develop, maintain and enhance good physical and psychological health.

The overall aim of the study was to establish whether there are relationships between meaning in life, sense of coherence and the ability to cope in young people. The specific aim of the current study was to ascertain whether the extent to which an individual has discovered meaning in life and the extent to which he/she has developed a sense of coherence predicts coping with stress in a late adolescent/young adult population.

\section{METHOD}

This research took the form of an exploratory descriptive study. Using quantitative research methodology, a convenience sample of male and female young adults, $(N=258)$ was selected with $20 \%$ of the sample being male. The participants, aged between 17 and 21 years, were selected from a tertiary institution. Certain biographical information was requested from the participants in order to investigate the limitations of the sample and possible differences in responses based on this information. Individuals were asked to disclose their age, gender, home language, and degree enrolled for. The language distribution was as follows: Afrikaans 15.8\%; English 53.4\%; Sotho language group 10.2\%; Nguni language group $10.5 \%$. Other languages identified which individually did not constitute a significant proportion of the data amounted to $10.2 \%$ of the sample. The participants all met the requirements for admission to a tertiary institution, which conducts all degree courses in English and thus participants were assumed to be linguistically competent enough to complete the questionnaires in English. In order to ensure that no-one struggled with answering the questionnaires in English, the researcher was available to answer questions and explain concepts. Language can indirectly be used to research underlying culture differences. Statistical tests (Analysis of Variance and T-tests) showed no statistically significant differences in responses based on any of the various biographical classifications. All partici- 
pants were first year-students and were thus considered to be exploring life roles, becoming independent, and experiencing a transition phase in a time of turbulence. Therefore all participants were deemed to meet the criterion of having experienced stressors associated with this life phase.

Permission to conduct the study was requested from the Higher Degrees Committee at the University of Johannesburg, chairperson of the psychology department as well as from the first year-psychology lecturers and course coordinators. The researcher presented a short five-minute information session on the aims of the study and other issues, such as informed consent, but potential participants were not given any directives that may jeopardise the results of the research. All students had the opportunity to take part. Participants were assured of anonymity and confidentiality and were instructed to not put their names, surnames or student numbers on their questionnaires. The researcher gave verbal instructions at every session and instructions for the various questionnaires were also printed above the relevant questionnaire. The researcher was present at each of the testing sessions. Students were informed that an abstract of the research would be placed on the first year-psychology website so that participants may view the results of the research. Participants were encouraged to answer as quickly as possible, as per instructions in the individual questionnaires, as they were informed that the first answer that comes to their mind is usually the most accurate one. The raw data were submitted to the Statistical Consulting Services (Statcon) of the University of Johannesburg in electronic format for statistical analysis. Statistical analyses are conducted in order to investigate relationships between variables.

The central hypothesis of this study posits that there are statistically significant relationships between meaning in life, sense of coherence and level of coping in young adulthood, as measured by the Purpose in Life questionnaire (Crumbaugh \& Maholick, 1981:1-15), the Orientation to Life questionnaire (Antonovsky, 1987:1218) and the Adolescent Coping scale (Frydenberg \& Lewis, 1993:1-233) respectively.

Three questionnaires were used which were all selfreport measures. In order to assess the extent to which an individual has found meaning in life, the Purpose in
Life questionnaire (Crumbaugh \& Maholick, 1981:1-15) was used which is founded on and aimed at measuring Frankl's conceptualisation of the meaning in life construct. This test has a Cronbach's Alpha of 0.91 and is therefore reliable and valid (Meier \& Edwards, 1974:384386; Shek, 2003:185-200). To ascertain whether or not an individual had developed a strong sense of coherence, the Orientation to Life questionnaire, also known as the Sense of Coherence (SOC) scale (Antonovsky, 1987:1-218) was used. The components of this measure are comprehensibility, manageability and meaningfulness and the scale has been shown to be reliable (Cronbach's Alpha 0.82 to 0.95) and valid (Erikkson \& Lindstrom, 2005:460-466). The Adolescent Coping Scale (Frydenberg \& Lewis, 1993:1-233) was used to determine the ability to cope in young people, with a reported Cronbach's Alpha of 0.62 to 0.87 and validity determined by Frydenberg and Lewis (1993:1-233). The measurement instruments have been used in previous research and were deemed culturally fair. The SOC (Antonovsky, 1987:1-218) is published in English, but is also available in Afrikaans and Tswana (Antonovsky, 1993:725-733). However, this questionnaire was presented in English due to the fact that all the participants were fluent in English, and since the Purpose in Life questionnaire (Crumbaugh \& Maholick, 1981:1-15) and the Adolescent Coping Scale (Frydenberg \& Lewis, 1993:1-233) are only available in English.

Various statistical analyses were conducted on the raw data collected from the questionnaires. Factor analysis was used to determine the internal validity of the measuring instruments. Graphical and numerical techniques were utilised to evaluate normality of the data. Analysis of variance was used to determine whether certain biographical variables such as age, gender, language and direction of study could account for any differences in meaning in life, sense of coherence and ability to cope. Pearson product moment correlations were used to assess the potential relationships between the variables. Thereafter multiple regression was performed in order to investigate the extent to which purpose in life and sense of coherence are predictors of an individual's ability to cope. Lastly logistic regression was performed to determine if meaning in life and sense of coherence could predict differences in ability to cope. 


\section{RESULTS}

In performing the factor analyses, factors were extracted by the method of principle axis factoring. The varimax rotation method with Kaiser normalisation was used in identifying the factors. For the Purpose in Life Questionnaire, a single factor was extracted from the second order factor analysis, providing statistical evidence for the test being used as a single measure. A Cronbach's Alpha of 0.87 indicated good reliability. A second order factor analysis on the Sense of Coherence Scale resulted in three factors being extracted, with a variance explained of $64.1 \%$. Good reliability for the subscales and the total Sense of Coherence Scale were obtained with Cronbach's Alpha 0.73 for manageability, 0.71 for comprehensibility, 0.81 for meaningfulness and 0.88 for the total Sense of Coherence. While Antonovsky (1987:1-218) suggests the use of the Sense of Coherence construct as a single measure, observ- ing the components of the Sense of Coherence construct would provide more of a multidimensional view of the relationship between all the variables in the study. As such the current study has made use of the Sense of Coherence construct both as a single measure as well as in terms of its individual components. For the Adolescent Coping Scale, the level of correlation did not support the use of a second-order factor analysis, and all of the questionnaire items were thus reclassified as binary data and analysed as a single measure. The Cronbach's Alpha obtained was 0.65. Graphical and numerical techniques performed on the subscale data indicated that all data were normally distributed. Analysis of variance performed for age, gender, language and direction of study indicated no significant differences in meaning in life, sense of coherence and ability to cope. Pearson product moment correlations indicating relationships between variables are depicted in Tables 1 and 2.

Table 1: Pearson's Correlation Coefficients between Purpose in Life test (PIL), Sense of Coherence questionnaire subscales (Comprehensibility SC; Manageability SMA; Meaningfulness SME) and Adolescent Coping Scale (ACS).

\begin{tabular}{|l|l|l|l|l|l|}
\hline & ACS & PIL & SC & SMA & SME \\
\hline ACS & 1.00 & & & & \\
\hline PIL & $0.64^{\star \star}$ & 1.00 & & & \\
\hline SC & $0.51^{\star \star}$ & $0.49^{\star \star}$ & 1.00 & & \\
\hline SMA & $0.60^{\star \star}$ & $0.68^{\star \star}$ & $0.63^{\star \star}$ & 1.00 & \\
\hline SME & $0.54^{\star \star}$ & $0.80^{\star \star}$ & $0.43^{\star \star}$ & $0.67^{\star \star}$ & 1.00 \\
\hline
\end{tabular}

* p-value $<0.05$

** p-value $<0.01$

Table 2: Pearson's Correlation Coefficients for Purpose in Life test (PIL), total scores on Sense of Coherence questionnaire (SOCT) and Adolescent Coping Scale (ACS)

\begin{tabular}{|l|l|l|l|}
\hline & ACS & PIL & SOCT \\
\hline ACS & 1.00 & & \\
\hline PIL & $0.64^{\star \star}$ & 1.00 & \\
\hline SOCT & $0.65^{\star \star}$ & $0.76^{\star \star}$ & 1.00 \\
\hline
\end{tabular}

* p-value $<0.05$

** p-value $<0.01$ 
From Table 1 and Table 2 it can be seen that there were statistically significant correlations between all scales and subscales. The correlations indicate that meaning in life, coping, and the psychological evaluation of situations as understandable, manageable and meaningful, are indeed related. The ability to cope therefore seems related to the extent to which one has found meaning in life, and to the way that young people make sense of complex surroundings on a psychological level.

Multiple regression was performed as a preliminary calculation using the original questionnaires, despite the difficulties encountered in the ACS second order factor analysis. Using the PIL, ACS and subscales of SOC, the regression model explained $46.9 \%$ of variation in data. Using the PIL, ACS and SOC as a whole, the model explained $41.9 \%$ of variation in data.

Given the difficulty in obtaining sufficient correlation for a second order factor analysis on the ACS, validity was addressed by reclassifying all items into a single dimension and constructing a logistic regression model. This resulted in a single scale which expresses an individual's ability to cope in terms of 'coping' or 'not coping'. Logistic regression is used when dependent variables are binary responses, that is when a variable can take only one of two possible values, but may also be used for non-normal data distributions. Logistic regression in this study was performed in order to determine if meaning in life and sense of coherence could predict differences in ability to cope. Participants whose responses were neutral and could not be classified as either 'coping' or 'not coping' were thus excluded from the analysis. As a result the majority of responses were excluded, however, following the reclassification of the data into a binary scale to address validity, logistic re- gression was considered the most appropriate technique for this type of analysis in the current study. The results are shown in Table 3.

As can be seen in Table 3, the logistic regression model was able to correctly predict 'not coping' with $97.6 \%$ accuracy, and to correctly predict 'coping' with $95.5 \%$ accuracy. The manageability subscale alone was able to accurately predict an individual's ability to cope or not cope with $92.1 \%$ accuracy.

\section{DISCUSSION}

Results indicate that there are relationships between meaning in life, sense of coherence and the ability to cope. These point to the possibility that the extent, to which an individual has discovered meaning in life and has developed a strong sense of coherence, is related to his or her ability to select health-promoting coping strategies.

During late adolescence/young adulthood individuals may employ inappropriate ways of coping with negative feelings, such as drug addiction and violence (Santrock, 2003:1-495). It appears that young people may benefit from assistance when making decisions that require meaningful action and the current study, corresponding to the literature, emphasises the importance of understanding how young people are able to cope with stressors as well as sustain psychological health and well-being.

There is a real need to find practical ways to implement intervention programs aimed at addressing meaning in life and sense of coherence, and in turn developing and enhancing healthy coping strategies. Results

\section{Table 3: Classification table}

\begin{tabular}{|c|c|c|c|c|}
\hline & \multicolumn{2}{|c|}{ Predicted ACS } & \multirow{2}{*}{$\begin{array}{l}\% \\
\text { Correct }\end{array}$} \\
\hline & & $\begin{array}{l}\text { Cope } \\
<3.00\end{array}$ & $\begin{array}{l}\text { Cope > } \\
3.99\end{array}$ & \\
\hline \multirow{2}{*}{$\begin{array}{l}\text { Observed } \\
\text { ACS }\end{array}$} & $\begin{array}{l}\text { Cope } \\
<3.00\end{array}$ & 40 & 1 & 97.6 \\
\hline & $\begin{array}{l}\text { Cope } \\
>3.99\end{array}$ & 1 & 21 & 95.5 \\
\hline \multicolumn{2}{|c|}{ Overall Percentage } & & & 96.8 \\
\hline
\end{tabular}


indicate that intervention strategies aimed at encouraging individuals to identify and search for meaning in their lives, and strategies aimed at strengthening their sense of coherence are likely to be effective in facilitating their coping. Sense of coherence is a global orientation which indicates the extent to which an individual perceives the world as understandable, manageable and meaningful. Therefore, how one perceives the environment could influence ability to cope. If individuals in the late adolescence/young adulthood life phase can develop adequate coping strategies while they are still young, they may already begin to develop a strong sense of coherence which will persist into their adult lives. Indeed Antonovsky (1987:1-218) states that sense of coherence is stable, and is unlikely to change at all after the age of 30. If they can develop good coping strategies while young, individuals may then be able to successfully manage their psychological health throughout the lifespan.

The research findings suggest that manageability is the most important predictor of coping among the constructs considered in the current study. The predictive ability of the manageability subscale alone indicates that the extent to which one perceives that they have the available resources at their disposal to meet demands is important. This implies that interventions aimed at enhancing a young person's perception of the environment as manageable and enabling them to identify their available resources may facilitate effective coping.

Furthermore it was found that there are relationships between sense of coherence as well as the individual components of sense of coherence, namely comprehensibility, manageability and meaningfulness, and the ability to cope. This outcome suggests that the extent to which an individual has developed a sense of coherence is related to his or her ability to select effective coping strategies.

Overall, it can be concluded that relationships between meaning in life, sense of coherence and the ability to cope do exist in late adolescence/early adulthood. Furthermore, it has been shown that the extent to which an adolescent has discovered meaning in life and the extent to which an adolescent has developed a sense of coherence or the degree to which individuals perceive life as comprehensible, manageable and mean- ingful are predictors of whether or not they will be able to select effective coping strategies.

Young people may benefit from receiving some assistance when making decisions that require meaningful action. The current study, in line with the literature (Damon, Menon \& Bronk, 2003:119-128; Frydenberg \& Lewis, 2004:25-37; Santrock, 2003:1-495), emphasises that it is essential to understand how young people are able to cope with stressors as well as sustain psychological well-being.

These results should, however, be interpreted with caution as the sample was fairly homogeneous. A second limitation of the study is that a large number of responses were omitted as a result of the reclassification of the ACS into 'coping' or 'not coping' for the logistic regression model. A possible augmentation would be the implementation of a model that would accommodate all three groups, including the omitted 'neutral' response group, implied by the reclassification. In addition, although the current study investigated young peoples' ability to cope with stressors, no attempt was made to determine what these stressors are and research is needed in order to identify exactly what leads to stress and compromises psychological health in late adolescence/young adulthood. It should be noted that although, based on the current study's results, it is implied that ability to cope is predicted by meaning in life and sense of coherence, this link cannot be assumed to be causal and it cannot be ruled out that an additional third factor could have influenced the results.

Future research could investigate whether the relationships between meaning in life, sense of coherence and coping explored in the current study are linked to specific stressors faced by young South Africans in the post-apartheid era, or whether findings would be similar for adolescents/young adults throughout the world. That is, research aimed at identifying the specific nature of health and stressors in various contexts could be valuable. Researchers should employ similar statistical techniques using the same variables with diverse samples in order to ascertain differences among individuals. It would also be beneficial for future researchers to focus on the implementation of intervention strategies that enhance well-being, including meaning in life and sense of coherence in order to facilitate adaptive coping in young adults in various environments. 
Some researchers (for example, Carstens \& Spangenberg, 1997:1211-1220) argue that the PIL test (Crumbaugh \& Maholick, 1981:1-15) indirectly measures depression. The PIL and the meaningfulness subscale of the SOC scale were shown to be very similar in this study, so their possible links to depression should be investigated.

\section{CONCLUSION}

It may be beneficial to teach young people coping strategies but also to develop meaning in life and sense of coherence as preventative measures for addressing stressors. Intervention strategies that enhance wellbeing (including meaning in life and sense of coherence) could be valuable in schools and tertiary education institutions in order to facilitate adaptive coping in young adults, for example, career guidance, psychological counselling, workshops, training courses, case studies, self-exploration weekends away, individual and group therapy, role modelling and mentoring of older students, and community involvement projects.

It is possible that programmes aimed at enhancing wellness will begin to, more and more, attract interest and allocation of resources from parties interested and invested in the healthcare professions. It is the task of psychologists to manage the psychological health and coping process of individuals and to create new ways of enhancing and encouraging coping strategies and behaviours within a salutogenic paradigm, in order to bring about health and wellness.

While it seems inevitable that young people will experience stress, it appears that enhancing psychological health and well-being may assist individuals in meeting challenging life circumstances and coping with psychosocial transitions.

\section{REFERENCES}

ANTONOVSKY, A 1979: Health, stress and coping. San Francisco: Jossey-Bass.

ANTONOVSKY, A 1987: Unravelling the mystery of health: How people manage stress and stay well. San Francisco: JosseyBass.

ANTONOVSKY, A 1993: The structure and properties of the Sense of Coherence Scale. Social Science and Medicine, 36(1):725733.
BROWN, KV 2001: The determinants of crime in South Africa. South African Journal of Economics, 69(2):269-298.

CARSTENS, JA \& SPANGENBERG, JJ 1997: Major depression: A breakdown in sense of coherence? Psychological Reports, 80(1):1211-1220.

COYNE, J \& RACIOPPO, M 2000: Never the twain shall meet: Closing the gap between coping research and clinical intervention research. American Psychologist, 55(1):655-664.

CRUMBAUGH, JC \& MAHOLICK, LT 1981: Manual of instructions for the Purpose in Life Test. Munster. In: Psychometric Affiliates. DAMON, W; MENON, J \& BRONK, KC 2003: The development of purpose during adolescence. Applied Developmental Science, 7(3):119-128.

FRANKL, VE 1992: Man's search for meaning: An introduction to logotherapy; $4^{\text {th }}$ edition. Boston: Beacon Press.

ERIKKSON, M \& LINDSTROM, B 2005: Validity of Antonovsky's Sense of Coherence scale: A systematic review. Journal of Epidemiology and Community Health, 59(6):460-466.

FRYDENBERG, E \& LEWIS, R 1993: Adolescent Coping Scale: Administrator's Manual. Hawthorn, Victoria: Australian Council for Educational Research.

FRYDENBERG, E \& LEWIS, R 2004: Adolescents least able to cope: How do they respond to their stresses? British Journal of Guidance and Counselling, 32(91):25-37.

LAZARUS, RS 2000: Toward better research on stress and coping. American Psychologist, 55(1):665-673.

LAZARUS, RS \& FOLKMAN, S 1984: Stress, appraisal and coping. New York: Springer.

LEIDER, RJ 1997: The power of purpose: Creating meaning in your life and work. San Francisco: Berrett-Koehler Publishers.

MARAIS, A \& STUART, AD 2005: The role of temperament in the development of Post-Traumatic Stress Disorder amongst journalists. South African Journal of Psychology, 35(1):89-105. MEIER, A \& EDWARDS, H 1974: Purpose in Life test: Age and sex differences. Journal of Clinical Psychology, 30(1):384-386. REKER, GT; PEACOCK, EJ \& WONG, PTP 1987: Meaning and purpose in life and well-being: A life-span perspective. Journal of Gerontology, 42(1):44-49.

REIVICH, KJ; GILLHAM, JE; CHAPLIN, TN \& SELIGMAN, MEP 2005: From helplessness to optimism: the role of resilience in treating and preventing depression in youth. (In: S Goldstein \& RB Brooks (Eds) 2005: Handbook of Resilience in Children. New York: Kluwer Academic/Plenum Publishers).

SANTROCK, JW 2003: Adolescence; $9^{\text {th }}$ edition. New York: McGraw-Hill.

SELIGMAN, MEP \& CSIKSZENTMIHALYI, M 2000: Positive Psychology. American Psychologist, 55(1):5-14.

SELIGMAN, MEP; STEEN, T; PARK, N \& PETERSON, C 2005: Positive Psychology Progress. American Psychologist, 60(5):410-421. 
SHEK, DTL 2003: Meaning in life and psychological well-being: An empirical study using the Chinese version of the Purpose in Life Questionnaire. Journal of Genetic Psychology, 153(2):185200.

SOMERFIELD, MR \& MCRAE, RR 2000: Stress and coping research: Methodological challenges, theoretical advances and clinical applications. American Psychologist, 55(1):620-625.

STRÜMPFER, DJW 1995: The origins of health and strength: From 'salutogenesis' to 'fortigenesis'. South African Journal of Psychology, 25(2):81-87.

STRÜMPFER, DJW \& MLONZI, EN 2001: Antonovsky's Sense of Coherence scale and job attitudes: Three studies. South African Journal of Psychology, 31(2):30-38.

VAN RANST, N \& MARCOEN, A 1997: Meaning in life of young and elderly adults: An examination of the factorial validity and invariance of the Life Regard Index. Personality and Individual Differences, 22(6):877-884.

YIU-KEE, C \& TANG, CS 1995: Existential correlates of burnout among mental health professionals in Hong Kong. Journal of Mental Health Counselling, 17(2):220-230.

ZIKA, S \& CHAMBERLAIN, K 1992: On the relationship between meaning in life and psychological well-being. British Journal of Psychology, 83(1):133-145. 